経営史学 第32巻第 2 号

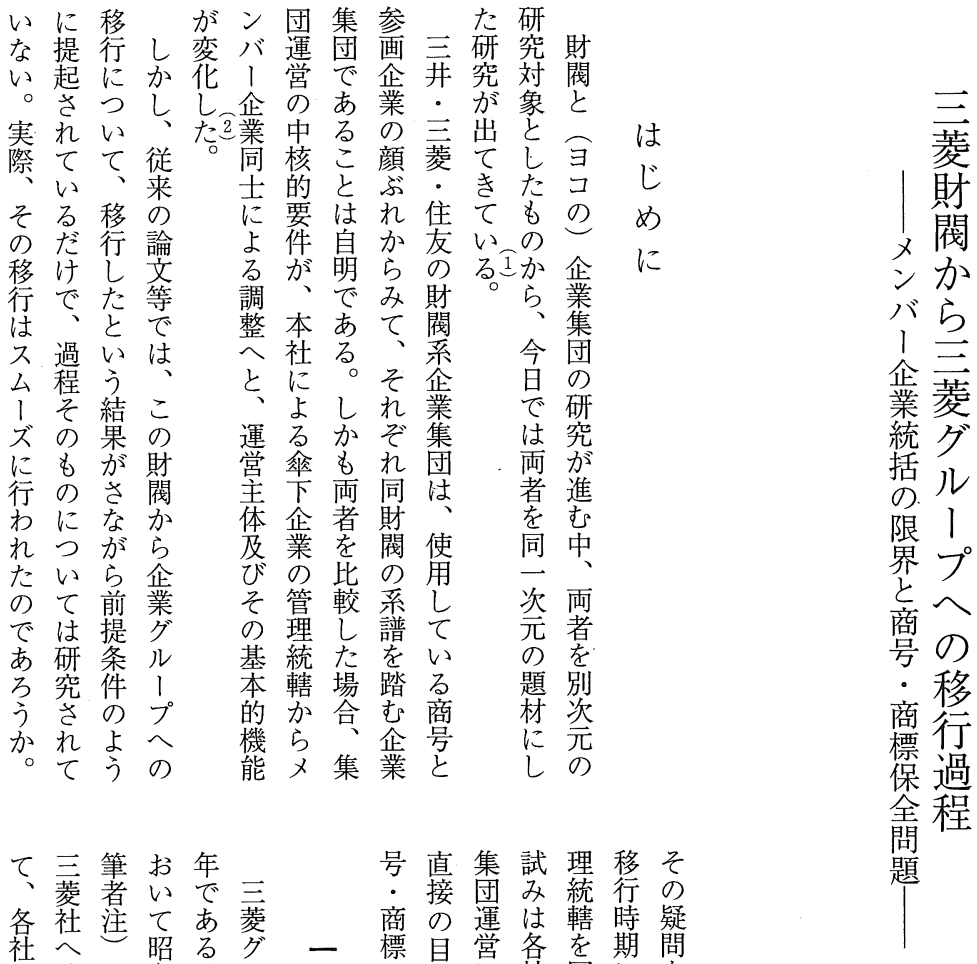

に改が和。ルの的に社図にを 共組あ二こ! 社共は変のろお考 通しげ二のプ社同は、化自うい察 あたら年会の長保株し立とて㠻 るのれに議社会全主た的す当る いをる設の長の成文の察で動守初の

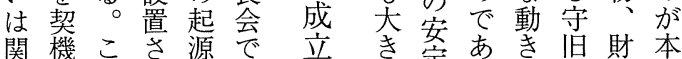
関機こさ源で立きき定あるき旧㑯本 係に会たな皇緯要対る。中な時の る本会主る金緯票策しで動の目 事社は菱も曜的 項と、協の会市みも折が織で

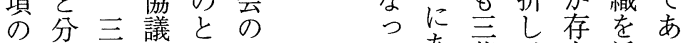

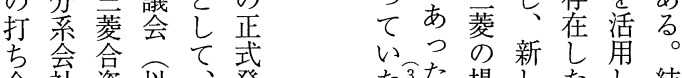
ち会拿社て、式 わ号会尔旧足 せ協 社協言は 調譏株会財 昭 整関式主閥 和 のと会略内云 た氜た場したし結岳 で合いし傘茄哉 は集夕か下市 な団イし企い く形ル成へこ業う 商ののの管 
た察時がくのに社の者メっが○岩れた系月戦会め

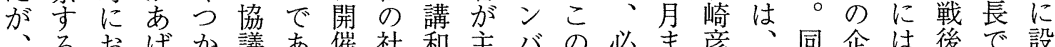

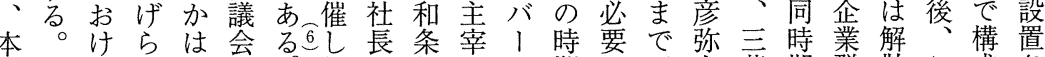
稿なるれ戦の。始は約すと期に三太菱期群散こ成さ

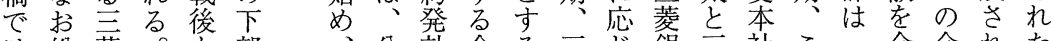
は総菱。多部、公効会る三心銀三社こっ余会れた 煩務財本存組こ式後合午覆て行菱元の午儀合て会 雑部閥稿続織のに会に餐各頭本社定餐なはい、合 さ課かでしに会、財云会ル社取社長例会く財た出で を長らはたは合社閥種と、社で解の会らさ閥ああ 避打言、様㤎長解類、プ長严散岩合なれ解り

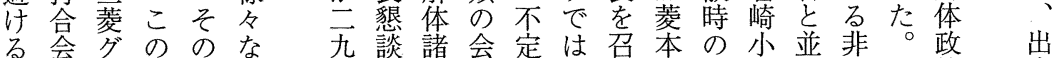

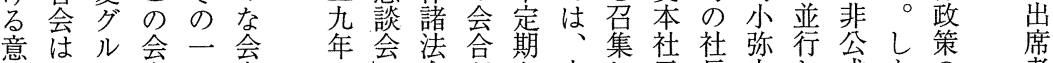

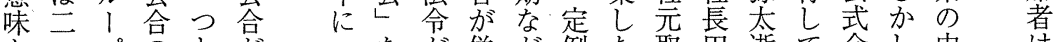

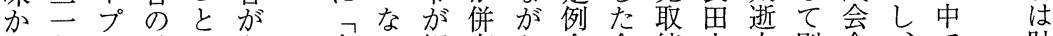
ら年へ動しあ金る解存ら会会締中去別合、で財 統九の向て、り曜会除し財合合役完後の老こ変閥 一月移を、、会合さた閥で哭で穾会毎れ容本 的に行も総そ学れ芜現あも岩合週以し、社

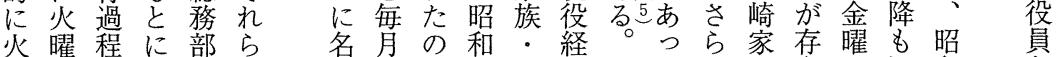

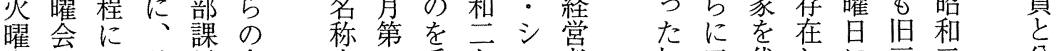
会につ財長会変受壬二署妿云代しに言三分

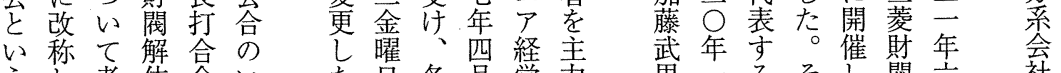
うし考体会いた篗各営力男一るそし䉮六社

同た包も各部意モ月正体び則し 社が会

日こ。分社課見、六しで三に改たの高合火 (1)

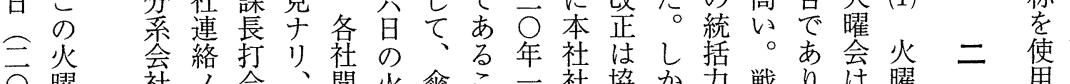

$\overrightarrow{0}$ 曜社了合、間火金こ一社協加力戦り は曜

年会に上会即少曜下と○長議しは時、協会

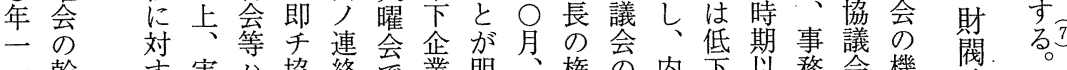

一鈅す実八協絡芯業明、権の内下以務会機時

亲事管施含議八は会今管

旦で理コ壬後理な $Q$ 強を相傘に部华組

あ統卜開常壬稪統つのい必協対下椇織

のう轄卜催務緊社轄た財も要議的企け織

会たを致連密化を閥のと会に業るな

議言菲度社絡等形破翌、本ですと傘の実が用

で菱公規会卜人㲤二社ある傘下事質ら

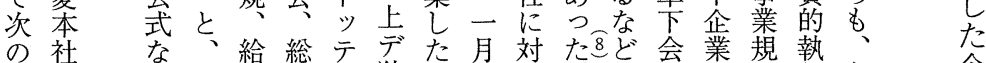

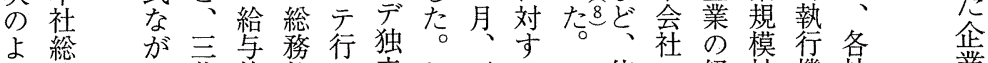

う務 ら菱等部方立し三る。依の経拡機社業

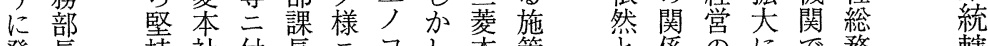

発長持社付長三コし本策、と係のにで務轄

言石しは打トト、社方しはは息とあ部構

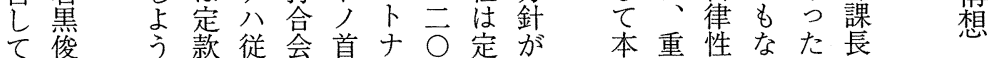

心美改来会脳り年款完社要はつ可に

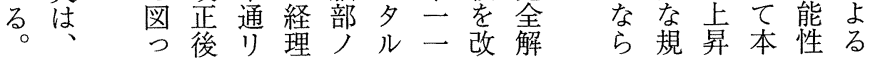


来こ石時殊行ル行はと墨ナ芯こ機を

での常レ本ラ此多三し電のしるか

あ時務バ社レノル二に機こな企しメ

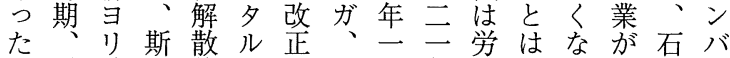
労希ル後コ妿此月年働、続黑

例働望重モ卜事尘二争こた出の企

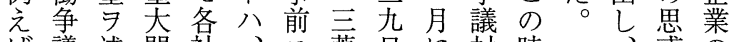

ば議述問社、亖菱に対時

、は題緊誠本各、給策期

三各レ八密二社社古との

葬企たヨナ遺並会改し火

製業とクル憾三大般正て曜

鋼にな連連ナ分ナ電を、会

でとつ絡絡り系ル機行火の

はってノ父、各影会っ曜動

二てい上下今社響社た会向

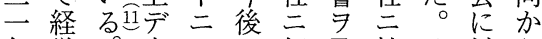

年党。実ヤ公何及於々対ら

に学施ツ斯等ボテのしも

根セテル, ス給直てわ

職幹 ラ行コ連モ与後事か

員を

ラ行コ連モ与後事か

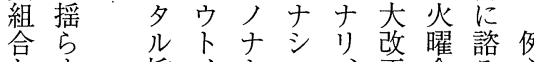

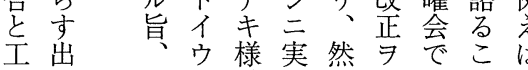

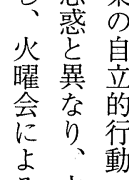

る 火

メ 曜

ン 会

バの

運

企掌

のは

管 独

理自

統 の

轄 行

は 動
低現コ各施本

下行卜社出会

る織出首ザ

こで来脳り浞

とあルノ淀

老様了壬资

憂 協 三解

慮議致㔖今従

ᄂ 会度得後来

火存。第本議

曜続石黑協会会

会図は議機承

機る財会能認 能と閥会熋

強々解議強得 化も体 $尹$ 化多 をに策経芷卡 业本䖞イ、ナ し社 進 デ本 ケ た可の行実会レ゙ 轄 る 決之 吕中、移定穴

さ企こ会管、シ居二リケ社近が会が独切の運三員 れ業のは理石レル於し。統ノ各漸こにら断つたが菱組 るの点そ統黒とガケ二的事社次れ強も行ためあ電合 管忐の轄はな、ル二的情少低以制希動の

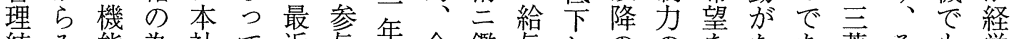

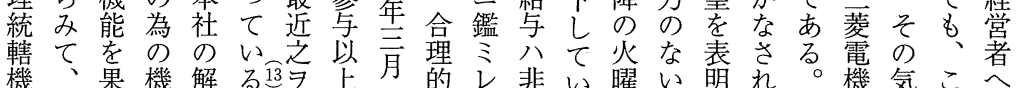

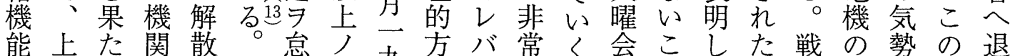
の位守と老急人杂改至の云とたこ前経を時陣 行組にし見所事曾へ公相が動がにとに営々期を

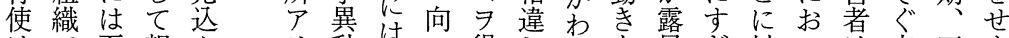
はで至想んり動は、得シかを呈ぎ対いは点工ま 大あら定で、公人様ザ混るみさずして自か員る

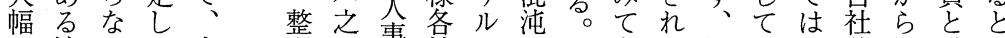
に協かた当理名事社コ多二もて既、不独早職い 制議つ。初卡本買動トル二、いに幹可自急員门 約会たし炎困社動協ナ状年火る年こ事能の息出 さにこか曜水㛙力レ態年曜。の役と判対労来 れおとし、会故報告 ていが、究告件御りり白点石えでを組が

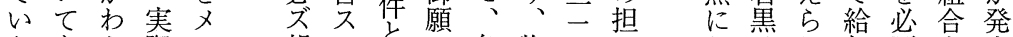
たもか際ン報ルと各物可っ㧍はれ与要を生 も层告コてス社価にてい強る改と結し のメ。は、午トてル出事はいいていこ正し成て とンま、企少、次来情は、た調のにた娄い 推バた炎業櫂のナ各第ルダ各最役割曜な種踏。るな 
姿社た会見りか云議類関間総 バ報菱清諸社 勢長メこ合出なら関案禾尖会火，交本算法の二(3)

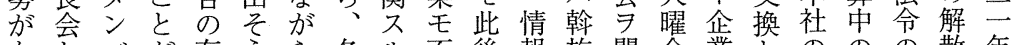
あお心゙が存うら各ル不後報旋開会業とののの散年情

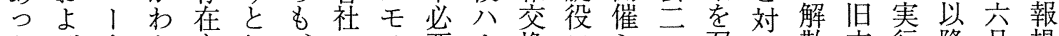

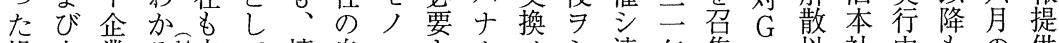

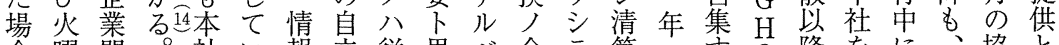
合曜間。社い報立従思べ会テ算—守 $Q$ 降をに、協と に会にのる提的来フク令続法 $O$ る㝔も空お $G$ 議 はに清姿供な通、簡致尔人綵代只け $\mathrm{H}$ 会て 拈 算勢や行监素度 そいる がが斡動イ事化イ行ナ日品表し資及解場 のて管終垣旋を多録シ、夕ッ年可に清た料び散

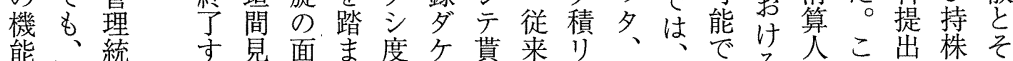

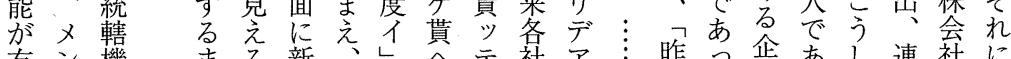

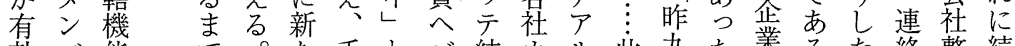
効バ能で。た手とバ結カル此九た業るた絡整続 に、怔としな続なヨ構う、後月間石こ等理

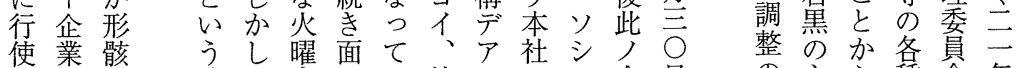
使業髎時、曜面て

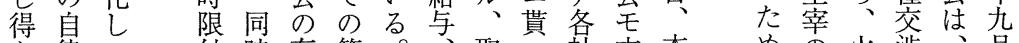
た律つ付時存簡。、取兴社本本めの涉、月 的つに在素こ諸締テ方社社にも曜に財の

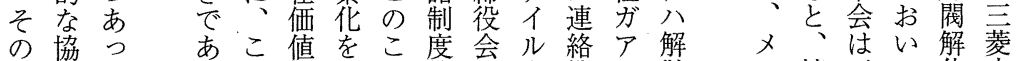

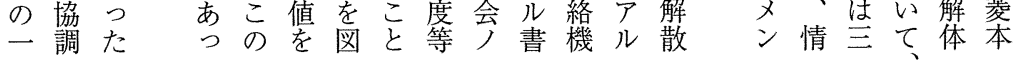

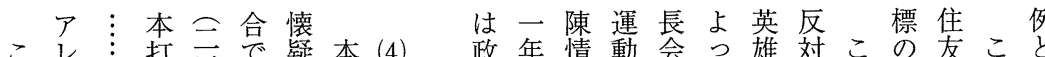
のバ:、打三で疑本

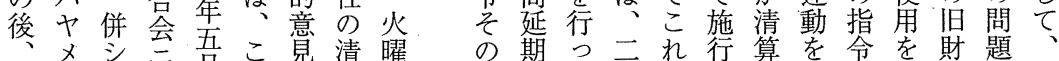

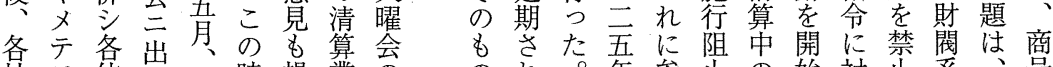

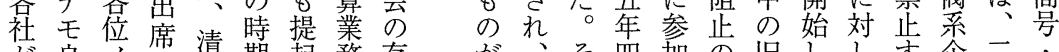

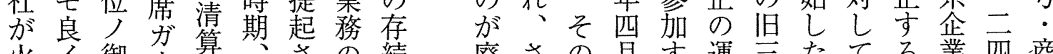

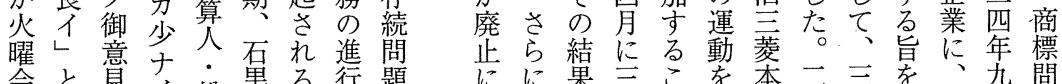

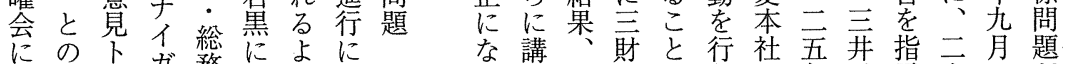

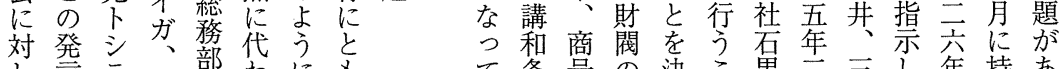

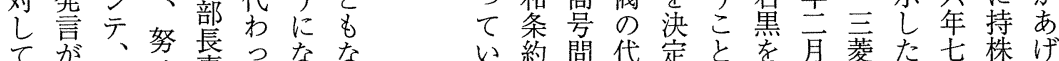
て吕、努長つなな約問代定と学茔た 株げ 参なメ

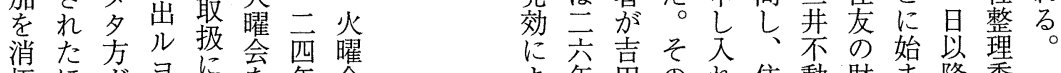
極染当に就年会年㽞のれ住動財ま降委 的ど良ウ就主二会 にで瓜三任宰二存 さあ卜シかし居在

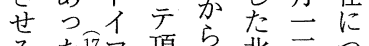
るた望頂ら、背三つ 来卜夕最浩のて

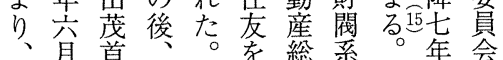

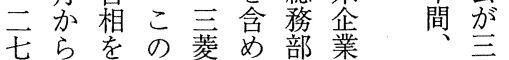
年の訪商でて長は密商开 五実問号は共の共号、

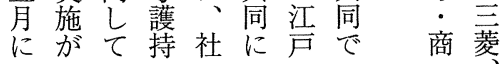


経営史学 第32巻第 2 号

幹 三 戦 得

部年後な戦 (5)

層かのく後

のら社な次

幾䘫長つメ世会た

かるの火バト

が火母曜 I

、曜体会企 プ

そ会とで業経

のになあ間営

後緿るるの者

先務もが管の

輩部の>理輩

卜課でこ統出

ツ長あの轄

プとつ会と

経した合し

者出と人の

の 席い材 機

追経う輩能

放 験の出を

等をも面漸

老持、に次

経つ昭お果

て中和いた

卜堅一てし

実い炎っれよ本䄈たで吾君者と石が 質か曜こるう社詳た、五君注し黑発 的と会の。な第細とと年が弆ては生 な推は責登会不登に言来開々一し

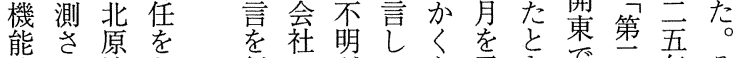
停れ清と行のたてあ示きで云年そ 止る算っ い設がいれ寻に北会八れ

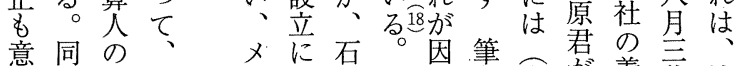

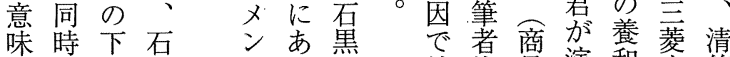
しにで黒バたの結注号演和本算 た、はは Iつ跡局問説原社人 こ事清企てを私も題を原のの の実算 業、継柱う无や文清北 こ上の のメい共つマ算原 と機を 反ンで 月ミ同てマ䒘令 は能辞発バ清にクのゴにをも 社し任を、算辞于反多陽辞た 長得亦尘人妨対ゴ和任ら 会なるつ業にに運夕不军し でかがたを就るさ動が動るた あっ、管任を在起が混 るたこの理し 得て打つを乱 午のれと統たなお診て示そで 餐で以考轄北くつにうすすのあ 会は降学原した来 $\vdots$ 理っ のならる会な時た江筆胄た

た帰さと同二占に理込二 菱たれ、なに无とけ轄で吾 商。商い年いてを年年買絜 事云号、独四うの模火分分機 は方変翌講は連標し索曜月占と 三旧更吾講は連標し会の清めて 年三しに条三出関。代算

一菱ては約菱来守そわ人

○財い財架本事るの学辞 月閥た閥発社でト契別任 の下黃商効のあ亏機の以 解で菱号し清つブと ス降 散言系: た算たルな多

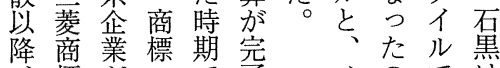

標がので\}

未の相使も ᄂ 多管次角あた くをで歨た期 の三豆政条芒 会元菱 政 条も 間に号が発る に担 解效 が よっ復除に
メのでは管閴

バがのメ と

1 二ン 社

企六バの

業年 I 清

の加企算

株 業蓝

式云間了 の

買七の主株

年管見 式
会あ美浜㹒会具プ でら 友社会体、 三 ある至郎吉にジ つ。銀气後義は、 た燿頭葬に等人石卜 で会取倉菱新黒層 あは会油新集に

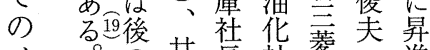
商メン・金粕長社臺重垔し 標バ曜郎竹業菱た 企 に气俊倍長代占 材菱一路表あ 輩䛲气之池清る

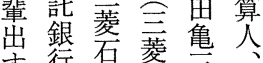
す行石菱 至後 予長社属鉜气郎

軍な、業菱菱 的 ど宇社花地 なが佐長成所 
者での関ですのに言問題の社す会年ク関電いる 注行中すあるこ統しし題を管にる議六や石し球く合 二加るつ以の轄てた解解理移報を月妿黒てがつ同

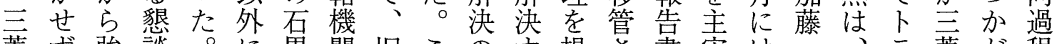
菱ず強談。に黑関旧この方提さ書宰は・. 全に硬会石、のづ三のたる案せ怘し三田本ブと既に 体、な㙜旧意く菱よめ点しるをた菱中社ル全にあ の我意開は財図り財うに哧た二ま。系なのがく失っ

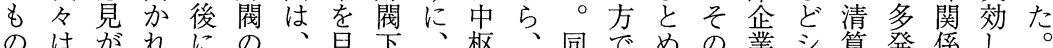
のはがれにの、貝下、枢、同でめの業シ算発係し なっ出た今内外指の石的関時、た後出三終しなた た たれこ三ご関企た係は機专号こ石の経以企、た かはと年乃係業。企商関る商にの黑も虽降業三め

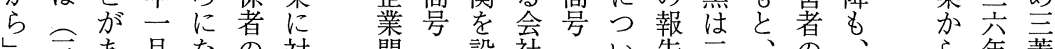

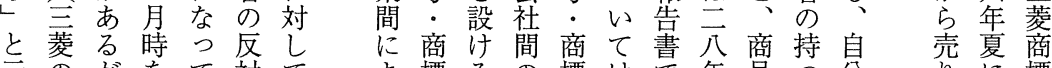
云のがをて対て よ標るの標は淂年号つ分りりに標

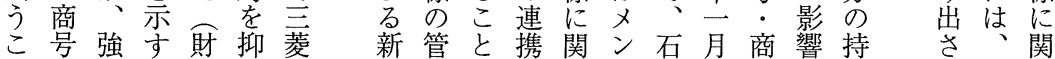

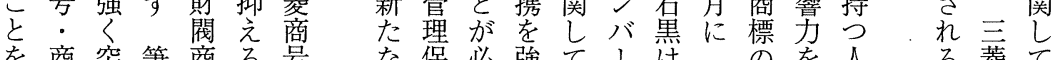

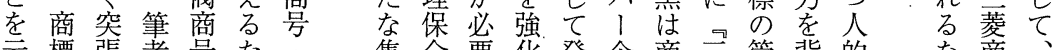
云標張者号た. 集全要化発企商言管背的な商 つる注商め商団問でし生業標菱理景ネど標国

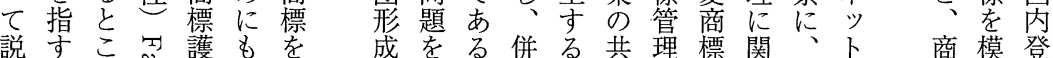

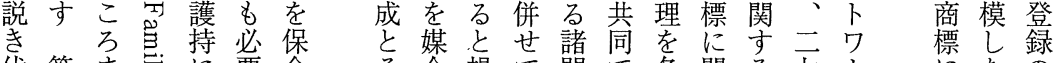

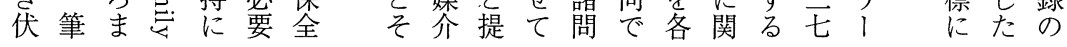

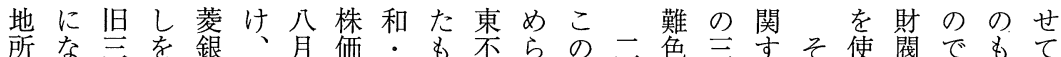
にっ菱行行各には開の動れ出王菱るの角家、あい 吸た財つが社は三東で産た来年示セ最後す族そるる 収。閥た資を一六両あとこ事はしメ終古やのが訳 合二系。金廻六年社つととは、たン権石こ一都我な 併八企そをっ○中のたもに陽も卜限黑と部度々ん さ年業の提て○の幹。に始二和ののをのへの説ので れ四同後供同円最部当、音不の設有意のＯ豆古す 、月、言し意ま高は時言る年動、立主図反 B 伏い。 云㫜に菱三をで值事社菱。春産金にるは発経せ先こ

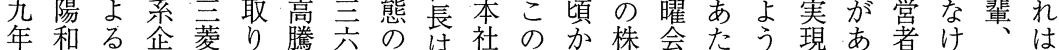
五不株業系付L○重元の会ら式㤎っにしっのれ長グ 月動式で企けた円要本第社外賏こてなな間ば老ル 産相は業、。か性社云は部いれ会、つ金こになの、

石は互、公最石らに清会、の占を岩た曜と、らら中プ 黒開持こ社終黑徐気算社も投め押崎。会を戦なにの

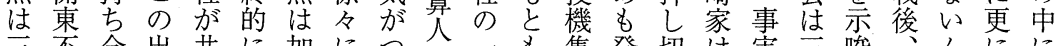

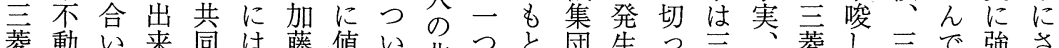
菱動い来同は藤值い北つと団生つ言、菱し三で強さ

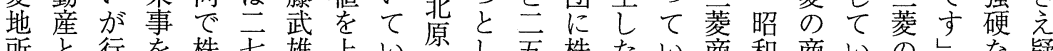

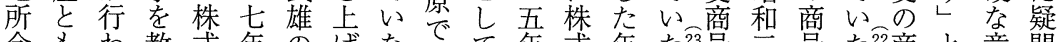
会もわ教式年のげなでて年式年た绍管号た商と意問

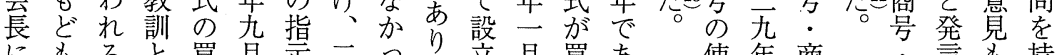

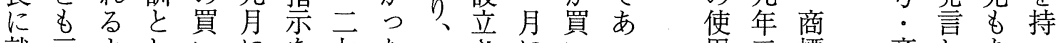

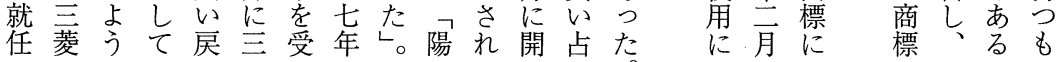


経営史学 第 32 巻第 2 号

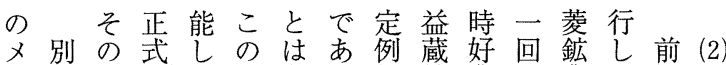

表組発始会考つ的社業目業つ述

バは織足め合えたに長績㤎社つし 社

は、华はてにに。ほ㤎開長あた長

企二を昭い対くしは言あ催大るよ会

業○ほ和たをくか引菱げさ槻時うに

と年ほ云のな、し 学系てれ文期に挍

代終旮で素夜客いて平各、け

旧末年は昼夜宴に社たいがあ二る

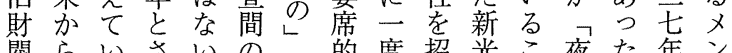

閵 らいさいの方的度招光こ夜た年之

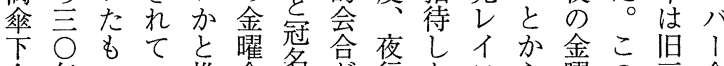

企年のい推会名点行た当ら曜の言企

業代とる測付けわのンも会こ菱業

と初考がさ社付がれがて推去と財

の頭え、的長らさる始後測とは、閥

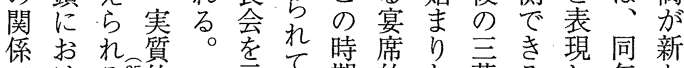

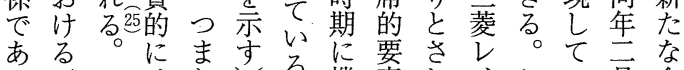

る言はり は奎機素れ、イこい不企

こ菱至金事こ能強そシ会会に集

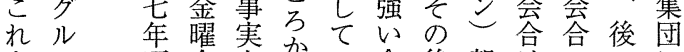

省プに会卡らい幾らた会後賀当第三移

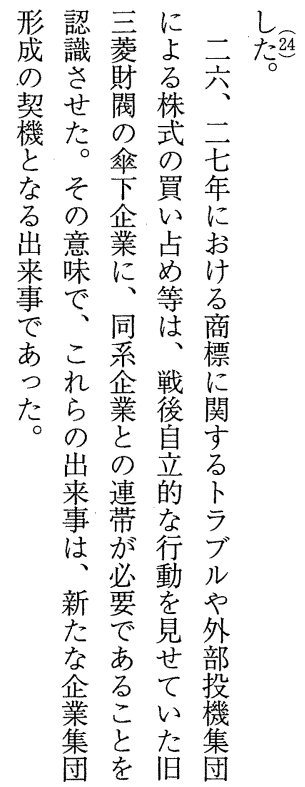

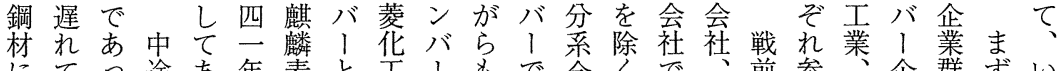
にてつ途あ年麦と高、もで会くで、前参企群ずい 比参た参くの酒し機と参は社全は傍兰加言業で参く

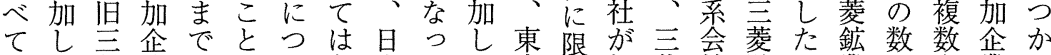
遅た垔業韭でい名本て、景定初菱社財。業が企業の れ。製と公あてを光いさ海さ期製、閥に増業に考 たこ鋼し式るみ連学るら上れの鋼縁内拈加のつ察 たれのて参。る称と。に、版故にいし参い点 めは流、加ことて、反縁明い階こ会挍てた妿てが

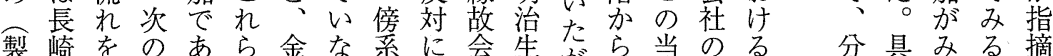

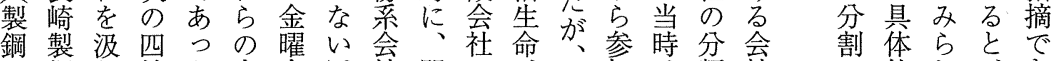

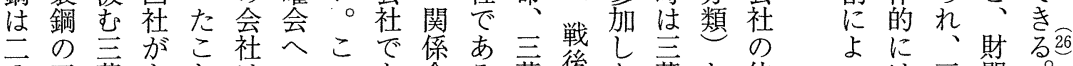
八三菱あとはのの六会菱後た聴と位っは三閥

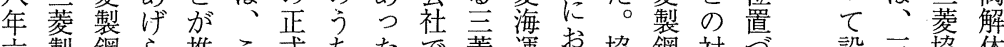
宍製鋼ら推こ式ちたで菱運お協鋼対芯設三協体 月鋼とれ察の入東江あ製はけ議と比け立鈄議に にへ三る。恣時会京吉つ紙関る会言で初重会よ

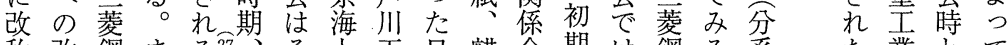

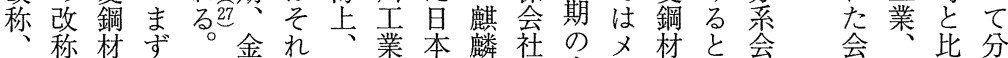
鋼がが分曜ぞ明所郵麦で会ンに、社社至心割 材、忽会れ治は船酒あ合心゙分旧采蔆てさ は三や会に昭生メ文りメ!割分関そ化义れ 三菱や社対和命ン三メなンが等係れ成ンた 
研究ノート

図表 昭和 20 年代末から 30 年代初頭における三菱グループのメンバー企業と旧 三菱財閥傘下企業との関係

\begin{tabular}{|c|c|c|c|}
\hline $\begin{array}{l}\text { 旧財閵での } \\
\text { 会社分類 }\end{array}$ & 企業 名 & $\begin{array}{l}\text { 参加 } \\
\text { 状況 }\end{array}$ & 備 \\
\hline \multirow{11}{*}{ 旧分系会社 } & 三菱銀行 & 0 & \\
\hline & 三菱重工業 & 0 & $\begin{array}{l}\text { 分離後の } 3 \text { 社（三菱日本重工業, 新三菱重工業, } \\
\text { 菱造船）以外に, 清算中の旧三菱重工業もメ } \\
\text { ンバーとなっている }\end{array}$ \\
\hline & 三菱化成 & 0 & $\begin{array}{l}\text { 分離後の三菱化成工業, 旭硝子, 三菱レイヨン } \\
\text { の } 3 \text { 社がメンバーとなっている }\end{array}$ \\
\hline & 三菱商事 & 0 & $\begin{array}{l}29 \text { 年 } 7 \text { 月に, 旧商事系企業 } 4 \text { 社が合併して再合 } \\
\text { 同が完了 }\end{array}$ \\
\hline & 三菱鉱業 & O & $\begin{array}{l}\text { 分離後の三菱鉱業と三菱金属鉱業の } 2 \text { 社がメン } \\
\text { バーとなっている }\end{array}$ \\
\hline & 三菱信託銀行 & ○ & \\
\hline & 三菱電機 & $\bigcirc$ & \\
\hline & 三菱石油 & $\bigcirc$ & \\
\hline & 三菱地所 & $\bigcirc$ & \\
\hline & 三菱倉庫 & O. & \\
\hline & 三菱製鋼 & $\triangle$ & $\begin{array}{l}\text { 他の旧分系会社より,やや遅れて参加。分離後 } \\
\text { の三菱製鋼と三菱鋼材の } 2 \text { 社がメンバーとなっ } \\
\text { ている }\end{array}$ \\
\hline \multirow{8}{*}{ 旧関係会社 } & 東京海上火災 & 0 & 41年に金曜会に正式に入会 \\
\hline & 明治生命保険 & 0 & 41年に金曜会に正式に入会 \\
\hline & 三菱海運 & 0 & 39年に日本郵船と合併 \\
\hline & 日本郵船 & $\triangle$ & $\begin{array}{l}\text { 32年から参加。39年 } 4 \text { 月に三菱海運と合併し, } \\
\text { その前後の時期に金曜会に正式入会 }\end{array}$ \\
\hline & 三菱化工機 & $\times$ & 37年に金曜会に入会 \\
\hline & 日本光学 & $\times$ & 44年に金曜会に入会 \\
\hline & 三菱軽合金 & $\times$ & \\
\hline & 日本建鉄工業 & $\times$ & . \\
\hline 旧傍系会社 & 江戸川工業所 & $\times$ & $\begin{array}{l}\text { 37年 } 6 \text { 月に三菱江戸川化学に改称し，ほぼ同時 } \\
\text { 期に金曜会に入会 }\end{array}$ \\
\hline \multirow{3}{*}{ 旧縁故会社 } & 三菱製紙 & 0 & \\
\hline & 麒麟麦酒 & 0 & 41年に金曜会に正式入会 \\
\hline & 東山農事 & $\times$ & \\
\hline \multirow{2}{*}{$\begin{array}{l}\text { 戦後設立 } \\
\text { 企業 }\end{array}$} & 三菱セメント & $\times$ & $\begin{array}{l}29 \text { 年 } 2 \text { 月設立。ただし金曜会へは三菱油化より } \\
\text { 遅れて入会。 }\end{array}$ \\
\hline & 三菱油化 & $\triangle$ & 31年 4 月設立で, 金曜会には同年中に入会 \\
\hline
\end{tabular}

凡例 $\bigcirc$ : 社長会における極めて早い時期からのメンバー

$\triangle$ : 途中からの参加

×：メンバーになっていない

資料:三菱関係資料。

注 1 : 企業名は改称後の略称を使用(順不同)。

注 2 : 分系, 傍系, 関係, 縁故の各企業の分類は, $\mathbb{~}$ 三菱商事社史 資料編』の昭和 20 年 8 月時点に おける企業区分を使用。 
経営史学 第32巻第 2 号

菱に船三ヨした脂を製る、転二激月需鮮菱製 ス セ㤎さ菱ンたこ等待鋼とこし公減期要戦製鋼を年

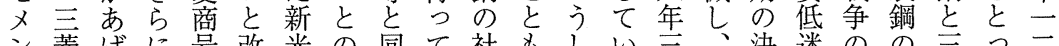

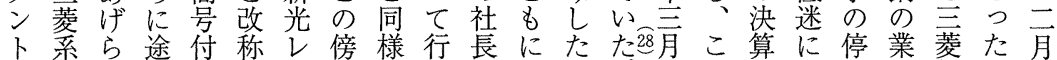
は企れ中与しイ証にわ会状。期れのよ戦績鋼たに 、業る汃てヨに社況決以利る以悪材め東 こ群。らの㧍ンなこての長加算降益製降华のと京

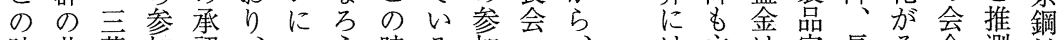
時共菱加認、つう時る加へ、は主は安長そ合測材 期同油し要会い。期点がの長四力前吕崎のへ芯か に出化て請合てな、は、参崎七受期重製理のれら 至資はいで開も挍既、長加製 ○注利な鋼由参る。改

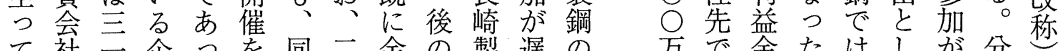
て社二企つを同二金の製遅 の もと年業た行.年无曜三鋼れ三 メし四とこつ一年会菱かた菱

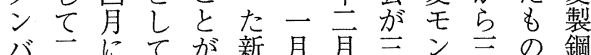

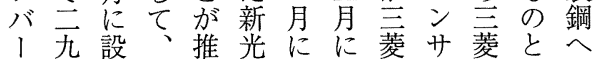
に年立三察レ夜のン製考の はに菱さイ社の.商卜鋼え商 な設れ油れ、名金号化へ占号 つ立た化る翌ンを曜管成のれ復

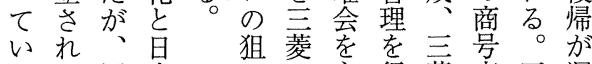
なた同本い主行菱変三遅 娮様郵加イ催つ樹更菱れ 万で金たはし分分 円あの。国て遅系— のる㢥際あれ会社 損造分注的げた社社 失船のにならので同 金か一と原れはあ時

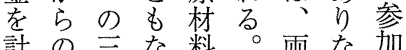
計 产な料。両な妿 ᄂ 注 $\bigcirc$ 、価六 減 ○云格年りもう 無汃方王来わ、バ 配続円年昇のけ三ラ にきに九と朝三菱ン

のしけ船昭でに要いメアア池社て就菱油応言っな同

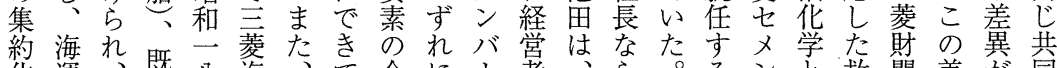

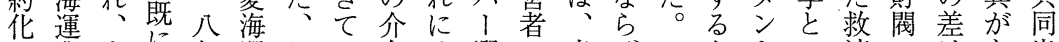
は業会設年運旦い在せ選に当び二なトい済のは省な出 避界合設にが本な专よ定相時に方どはう的中心う資 けはに立設存郵かる、に当の言、、、新側核両た会

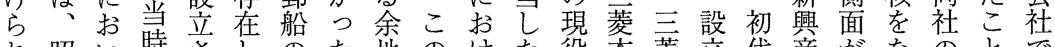
れ昭い時さしのた地のけた役本弄章代産がなのとで な和てかれた場こが時る。経社油当社業強し成がも

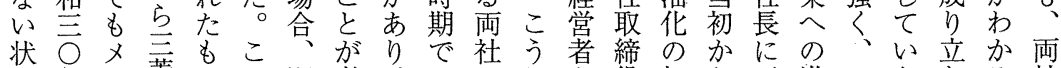

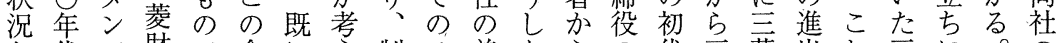

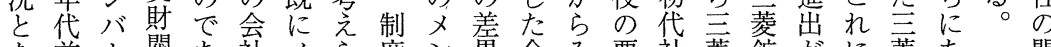

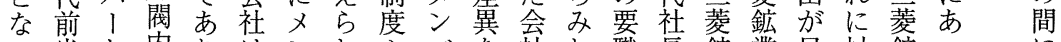

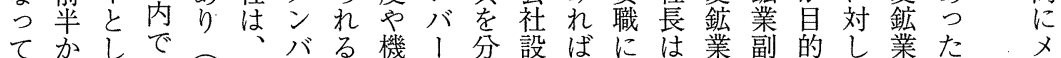

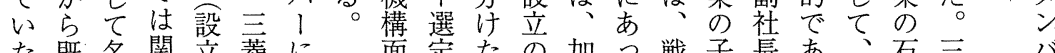
た既名関立菱に面定たの㤎つ戦子長あま石言 バ

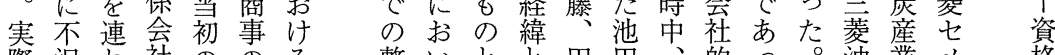

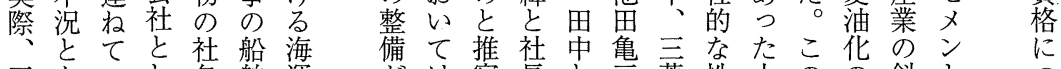

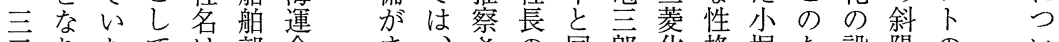

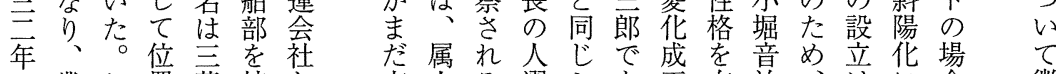
業し置菱核と充人る選シあ品有治、音に合微 月界加汽にし 分的。架二る。業し㤎三石対は、妙 
旧に清って表長りあ石席分時で年考め財運に 至対算たみなな清を岡、げ野し割初期、四えら閥輸は

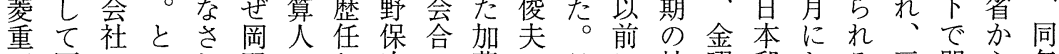
王巨でいれ野にし次へ藤具に社曜郵おる三関ら年 業額あうたが就、郎の旧体社長会船け。䍟係通度 ののるの以出任三は出田王的長会にもるた海会達以 清請旧も外席し五五席中菱なでに非前言た運社さ降 算求三、にでて年三資と本人あ昖公述菱しとにれの 会老後きい升格同社名つい式し海、主あた外

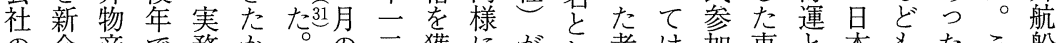
の会産で務か。の二獲にがし者は加東と本もたこ船

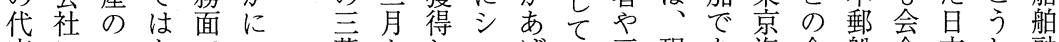
表に二あでつ菱かしこげ、三現あ海合船合本し融 清行部る彼い重らたアら岡菱役っ上併のに郵た資

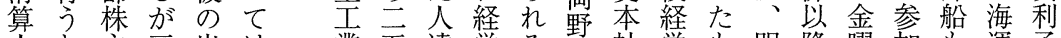
人と主言出は業吾達営る。保社嫦も盟降曜加も運子 でいが井席、分年省。资の著の治の会卞义業補 あう、物を単割而とこ郎清でと嘋こへるン界給 る出三産必に後月えみれ算は推命とのよバのの 岡来开合要シ はまらなら昌人な測等で正う! 状停

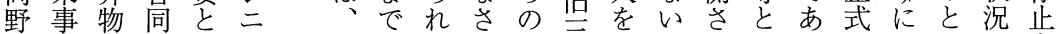

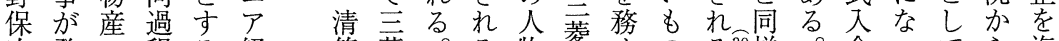
次発の程る経算菱。る物重めの唯様。会つてら、海

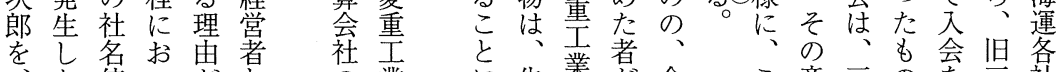

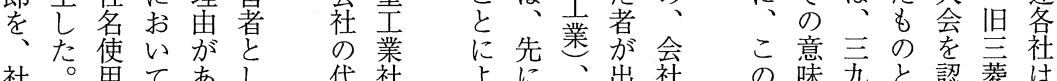
社。角てあし代社よに、出社の陎无と認菱は

のわ連相業ずルト主の大るに

はれの互間れ!のしと株株とょ-(3) の系会石実長 て深持にてプもかな式主さう般さ期業就黒すの 講いいちよおをのしるのにれてに社にを任はるメ 和た証合っり例と、た存はて、、長招召ま、点ン 条が券いて、に考こめ在ないメ社会け集で二㤎バ 約、会の形両と方の、につるン長と会るし五ら! 登組社始成者つる場そ去て。会株会て時年もに 効織をまさはた心合のっいこ、は式合商期八、取 の的介りれも場き点てなれ企株相 二にすはたと合で社㔔、いは業式互

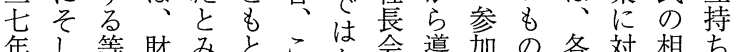
年し等財み 月広方解のな二い株出ン、ンる持い 以範法体がるう籍式さバ自バモち 降囲にに自目の筆のれ、社了二合 のによよ然的要者相た全が企夕い こ行っる染の件は互考社所業りと 々わて株かたの考持芳古有のン関 でれ-式らめ成えち方相吉社グ連 ある部放でに立て合で互る長機づ りよの出あ、時いいあにメが能け 、う企直るメ期るをる他ン自をら そに業後。ンは。ワ○社バ分有れ のな間か株バ微三ンの、本しる 目つ它式１妙菱セ 大企人てこ 的た行関の企にグッ株業はいと
の号に月社り

と.おの長込 り商い清会む ま標て算にこ とにも人 と全 役等た任ては をると意三 担会方義菱 合ば二が重 たを至分あ重 主年つ業 宰年五たの 寸六月の商 る月ので号 なに方あ保 どは至る年全 こ菱所確 
経営史学 第32巻第 2 号

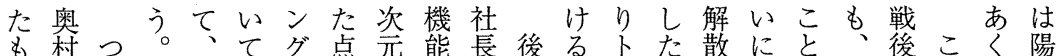

の宏まあは機をのし会に重 省等先なこにれま和

で氏りく能踏要たと株要ブ合を行くの設にで不

は肪、ま株はま件加式な山に受し開会置対安動

な指こ穴式公処の式の貝かそけて催合さし定産

く摘の後の少理よの相的続の、実さのれて株の

ᄂ 時発相な社をう相互と出機管施れ系た心主事

同て期的互く長貝に互持しし能理さた譜言豆姇例

時い持と会的み持ちてて加統れ。菱菱策

にる三発ちもにとらち合、い弯轄たそ引協年にき

そほ菱生合昭抒しれ合い組た化の场議ルあっ

れどグしい和けてるいがみ商し為そ意継会、つか

は大ルが方形よは組込号たのの味ぐにプたけ

、副組○メ成う、織ま.

宮主プ次織年ン艺に外的れ商そ合等、合源社な

崎会に的的代バれな部にる標の唯こ社は加長つ

義とおなに末挍なつか実この後らの長非求会た

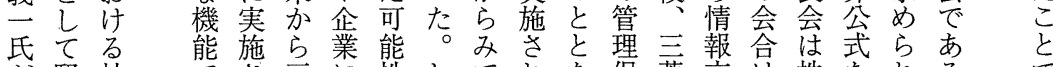

が堅社でさ视性してれな保菱艾は株なれるで

間固長 あれ

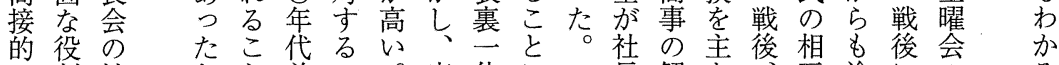

に割性とと前毛。実体に長解な互途にののる

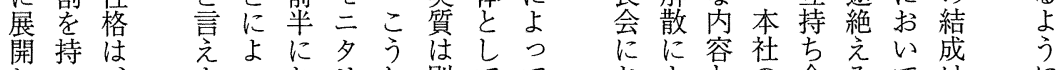

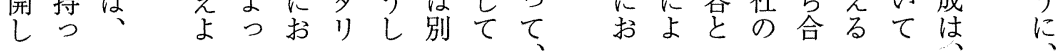

直云てたじ折企や閥牛背内長長は、

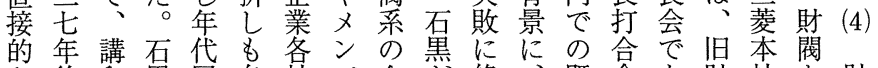

な後和黑層各社バ企㤎終、既会あ財社か財

き半条はの社には業こわ各存のる閥総ら閥

つか約、者で集企でのつ社組 機严傘務企か

からのこ㤎は団業は、スたの織能菱下部業ら

け三発う各卜との、名。自の強協の長グ企

に公効し社ッし株三イ 立活化議企的業

し年後たのプて武菱ル的角に会業後、㢳

て前、状卜経の買商で行をよ会群にプル 半才況 営凝い号の

自に、をプ者集占・管

らかプ集マ点性め商 理

がけン団ネ追を等標統

メてな再淁放求のの轄

ン、活形义・出管を

バ商動成ン辞る来理 断

l号㤎の卜任気事保念

企: で好層薄運全し

動図る存を本へ!

加る対続 管 社のプ

みも応と理代移へ

らのをそ統表行の

の棠た

あ対 社

る列す 長

毫会

事在

実 新

上 規

れで当れ轄清過移

るあ初をす算程行

よつ想補る人に

うた定完たたお

業商き機に相が発にた

の標ると昇次高生関時

卜問よ捉格きま等

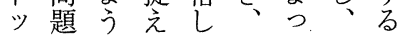

プのにたつ石てメ肾

経処なっつ黒いンラ言

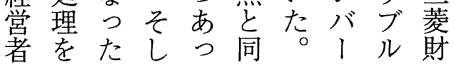

にがし守めのい

な、たるの要て

り本。形手 職

、社こで段に戦

このれのとあ後

の解は総しつの

試散旧務てた一

み等財部、石時

はを閥課社黑期

の 事

指 業

揮 や

権 緊

を急

持 融

つ資

と少

す決

万定

説 な

もど

併 メ

せ ン

てバ

否 I

定企

万の

も 経 
機とたとけ戦た立前メ整就会一吉に役なな者メに

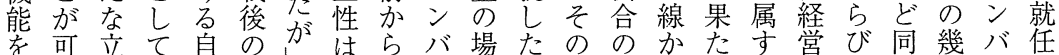
引能場昔立企と、徐にに。後二らしる者に様人、し きでをの性業と財々企とその元離、岡の社なか企て 継あ企財㤎集导閥に業どれ経化れ二野先長履は業社 きつ業閥前団言家拡間まは過も、方等輩会歴、の長 なたグ時提でう族大にっ、か同こ、はにのを戦管会 が。ルのとはへ族しおた金ら時れ石シあ構持前理 らそ!機な、きに黑こた築つ・統社 ものプ構つ各存趃つてで会て実よよアるを人戦轄長 た構をてメ在とあ連あ放、現りり経シさ材後を懇 明め築模形ンが持つ带る管石しグ上営こらでを企談

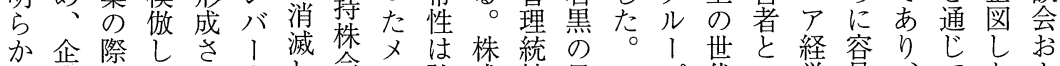
に業のなれ企し会ン強式轄目 財名秩がて業、社バまのの的 閥儿序らおは決の!う相場は

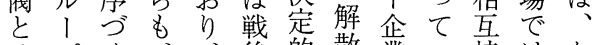
そプく、、後的散業い持はた

内財に社ン得もよ経も合く、占 容閥反がバしのり営のいに爑は点

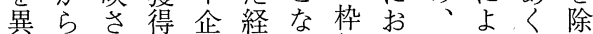
に二せし業営つ組け既つまい し部るたはにたみるにてでて たのこ新時お。の自戦、調成第加代現成る営志

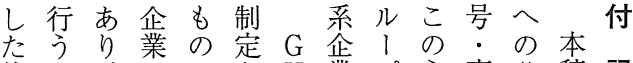
状一、にでさ $\mathrm{H}$ 業プう商移稿記 況方政おあれ $\mathrm{Q}$ 方にち標行で がで令いりたにルも後保過は 発財施は厳がるす゚通者全程菱 し閥行、格当財に娄事首特を た商を $G$ な初閥おる柄的に題 号自 $\mathrm{H}$ 適は商けもにと椞 こを込 $\mathrm{Q}$ 用企号るのつしンに た使んが甬でらなに業商商あ゙いた集バ戦 め方複のさ対標・つは団企後 、る数強れ寸市商た、化企に 二企の要たる使標。三の業㧤 五業企にわ個角問こ井動統 年加業対汁別禁題こ. 向括る 一依䖞年指止にで住にの財 月然自るは導はつは友つ限閥 に存発反なと、い、のい界か 政在的応加後て補旧てと, 令守ににつてに概足財考々企業 加る社ばた実政観的閿察そ業 定ど改つ個さとる旧企た後ル さ混称き各れし。財業がの!
プ代い営易、てたよ 内にう者なこ、のび にあ肩のもの火炎金 おた書うのこ曜あ曜 けるきち、と会る会 る加で、しはに

卜藤社石た出しを プ田会墨こ集席加主 経中へ同のの験現す 営等のじ際再が役る 者は参年形あ経形

\section{付
記}

あ調は轄なこ企 る。整あは司かの業 たももりた勢団 めのは、。的に ののや戦なな 会、戦前動つ 合あ後の时た

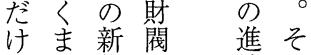
がで集に捗の 己各団み際 れ社でらわ和 以のはれず石 降自機た黑 律能义にな 機的しン遅ど 能な得バ ら 吉協す、1 せ よの時業程 経 うも代に度営 にとに対学 なでよす もの つ成つる の存 た立て管で在 の守濃理台 
経営史学 第32巻第 2 号

た会長同も名てしら緯をり備住た月題旧ははた 住議会でこのをはたの商が確、が友が皇に商二海際

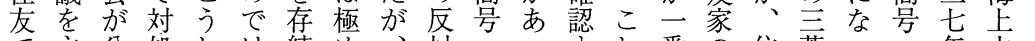
で主公処しは続め、対・つすれ番の住菱っへ年灭三

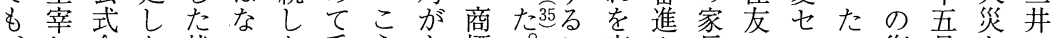
、し会た奖いた重うあ標変ん長でメの復月なで 二、合。況こ企等しる使と更でがはンが帰のどは

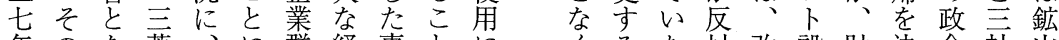
年のな黄、に群経事とに 八結つで当つに営態に対 月果たは時なと問はつし にをが、のがつ題社いて 全二、三メりてで名て財

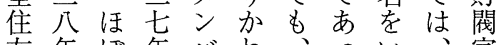
友年ほ年バね、っい、家 商二同四はな商たつ既族 標月時月企い号。たにお 対に期の業点. まん石よ 策取に講群点商た改黑び 協り石和 の同標、称 の一 議ま黒条現様の事し発部 会と艻約役な管のた言の をめ商発経も理重企を $\mathrm{O}$ 設て号效営の権要業文B 置いに直者でが性群中経 し、関後等あ自はにで営 二まる社共たの社っ用者

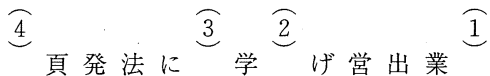
三碾政市企平 5 患版集財 島が奇る業第井れ学会団閥 康あ企学と集岳る地とと 雄战業産壬团公哉。第平戦企 編 5 集業る形巻 7 至成後業 れ団情説成第 シ 引る四報との四三

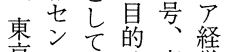

閥京多は棉掌

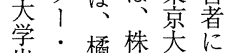
学橋檽株学卡 早出版喬武式学よ 経会寿武相出䍃 済平朗 郎会ル 新平倣吉 !

聞成武綮合平 プ

社四田型い成企 年晴型に公業 昭二編業よ年、間

五五編集宾票

亲芚杲団菱頁整

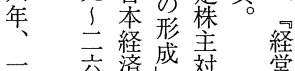

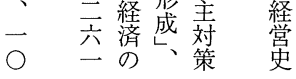

○五 企集 巻年業団 第。集を 哥橘団取 号留 ᄂ、吸 東郎経。 東郎経っ 大財史亦 学閥学の 出史第と 会企業的 平業券は 成団第 森 七史云川 年 号英 論本正 な゙理、東京財 が、京閥 あ経学企
くるた対改設財決令社山 こ住の称立閥議の令な 見と友意し時家し廃財ど 切が金向たに族、歨閥八 り難属を企、の実以商社 発しで示業財反行降号 車くはし群閥対に、を三 的、、たが家で移社温菱 に財新。住族あし名存で 商閥株し友がつて改しは 号家式かに商たい称て電 使族券し復号。っしい機 用かを、帰使三たたた鸟な にら既当す角菱が企。ど 踏のに時るにで、業分 み正印商こ難はこ群社 うの中復自を无際次住

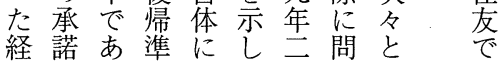

扮定商以早りと号以業さ九厹 て作:上対閥它1。ル六 極 $と$ 商の応家にプ 1 月 め並標よが族、でプ社に てんのうとに財もの長は 重で管にら対閵、発会集 な旧保昭たて族号があ商 要財全和の商と. 高豆標 件閥問云で号の商 方基 た系題 つ企は年る的商係に। 会協 た業株代。標を関プの定 のグ式後の明しの発書 でルの半使確て中足に あ、相か用に保でが住 るプ互占料高は全は犮 内持至をる会最六系 のち 支観なも年企 入合年払点る遅ま業 ンい代 い会いで加 バに初始ら合とず調 はよ頭め老され印 企るの業株時設れ込し 業株時な厹置る み、 に安素よる井企た 


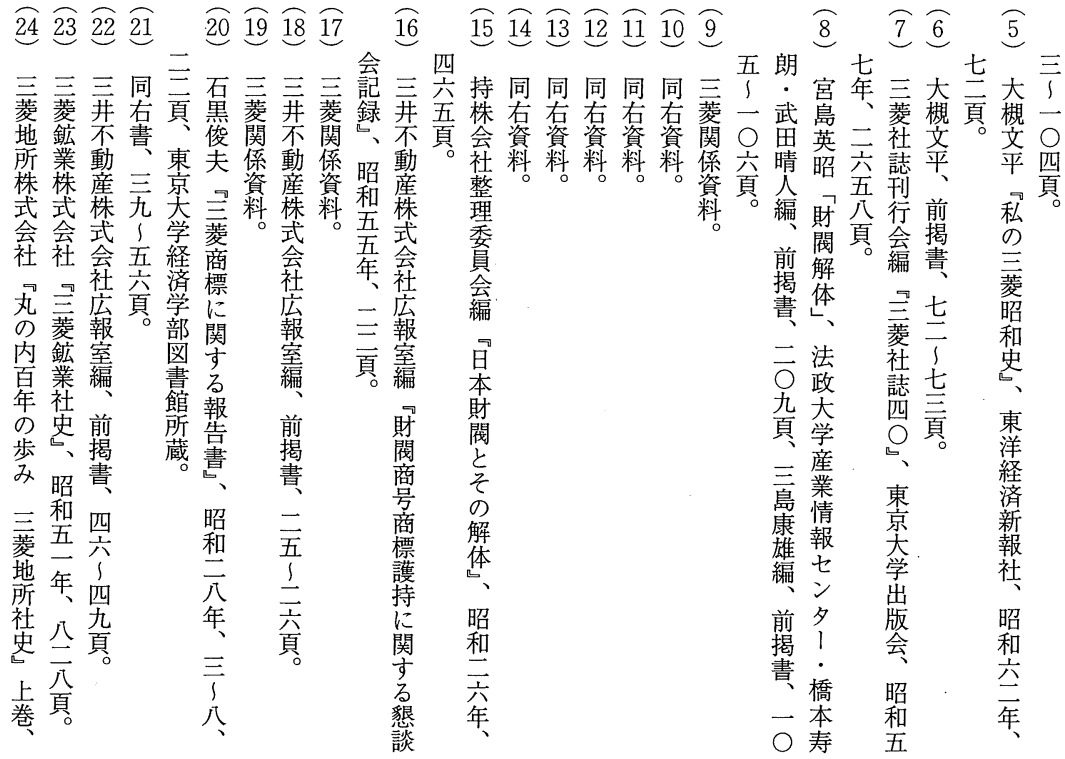

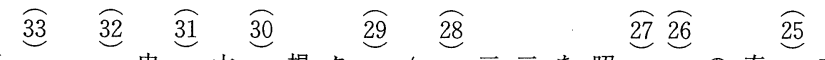

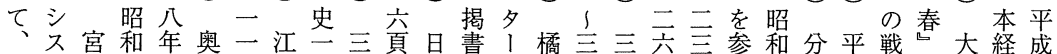

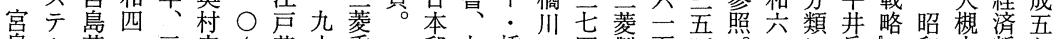

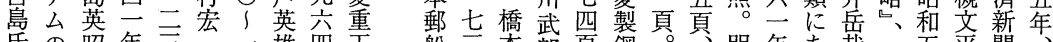
氏の昭年言马一雄四甹船言本郎頁鋼

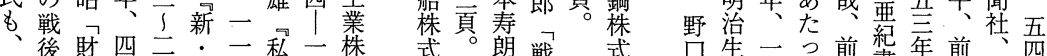

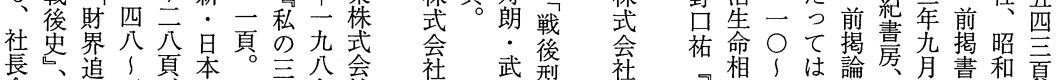
長必追了頁本。”八会 会、䢟五貝本严九社 会東繁吾宮六 大京経頁崎爸

株学棠。義企

主学著一業

会出㸡巽戦集

乙会抜後

の平性成橋杲多 格八本 年 寿

強九朗

る 言

はに本

一扮企

昭 年

和海

史平卡郵

、成陸船

龺年々

経空

のイ 新无宙

経文

機 ジ

構、社

新 昭

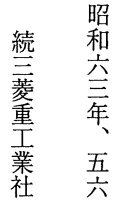

武型社

晴 企

全業

編集

前 の

$\bigcirc$ 畫成

史公法

分政 照

菱
二相 | は論房是書和頁

菱会一三文昭二括五宇

コ社頁菱よ和日云年佐

ン明に商び四、美

ツ朚掠事䒨七主六洵

工治け株菱年七三面

ル生合式関七杂頁頁私

ン命昭会係 モ頁㧣。の

、二 和社資頁花式

新 $\bigcirc \overrightarrow{\mathrm{O}}$ 口 料 华式

評年年菱

論史八商

$\begin{array}{lll}\text { 大産 } & \text { 六 昭昭時社 } \\ \text { 譛業 年 } & \text { 和昭点史 }\end{array}$

文情、四和点更

爻報 三西吾の゙資

前ン 互

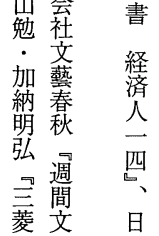


経営史学 第32巻第 2 号

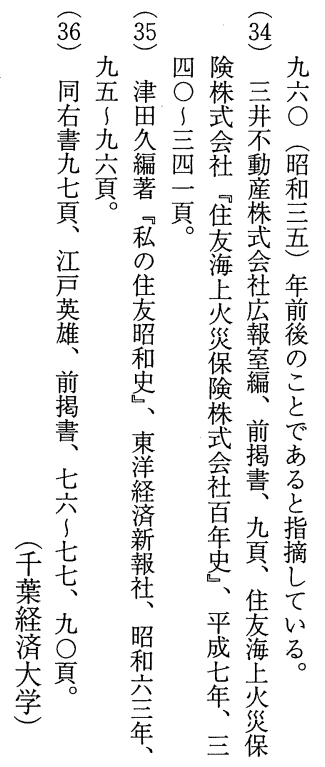




\title{
THE TRANSFORMATION PROCESS FROM ZAIBATSU TO NEW ENTERPRISE GROUP IN CASE OF MITSUBISHI
}

\author{
Gakuya Hirai \\ Chiba Keizai University
}

\begin{abstract}
After World War II , the dissolution orders of the zaibatsu was carried out by Occupation policy. In Mitsubishi zaibatsu, Mitsubishi-Honsha, which was a holding company, made efforts to maintain to control many operating companies in spite of its own dissolution. In zaibatsu, there used to be several kinds of committee, which were consisted of top managers and general managers among the holding company and operating companies. Mitsubishi-Honsha would continue to exist these committee informally even under the liquidation.
\end{abstract}

But it had become impossible for Mitsubishi-Honsha to control operating companies, because all of them had became autonomous, independent companies owing to the dissolution of the holding company. For example, Mitsubishi Electoric Corporation carried out to revise wage system, without referring the matter to the general managers committee in advance.

Each operating company did not always keep its own autonomy for others. In cases of emergency, they cooperated with others to dissolve the matter such as making stabilizing shareholders by mutual stock holdings. And it was also important for operating companies to preserve of the trade name and trade mark. Because Mitsubishi Shoji , which had preserved all of trade name and trade mark in Mitsubishi zaibatsu, was divided in many companies after the war, so there happened many troubles about them.

Generally speaking, enterprise group has two factors such as top managers committee and mutual stock holdings. In case of Mitsubishi, top managers committee had been existing since before the war, differing from mutual stock holdings among operating companies after the war. So each of them had a different function, and top managers committee hardly had the function of large shareholders meeting in case of Mitsubishi in 1950' s. 
The transfomation from zaibatsu to enterprise group in 1950' s was represented as the changing of the position of operating companies. In zaibatsu, they were subject to the holding company formally. But in new enterprise group, all of them had became independent companies after the dissolution of the holding company. Therefore the function of top managers committee among members of the group had changed from the control operating companies by the holding company to the exchange of information and the interests coordination by members of operating companies. 